\title{
Spatial deixis in Lithuanian: demonstrative pronouns
}

\section{Telpiskās attieksmes lietuviešu valodā: norādāmie vietniekvārdi}

\author{
Gintarẻ Judžentytè \\ Vilnius University, Faculty of Philology \\ The Department of Lithuanian Language \\ Universiteto St. 5, LT-01513 Vilnius, Lithuania \\ E-mail: gintare.judzentyte@gmail.com
}

\begin{abstract}
This article deals with spatial deixis in Lithuanian (the issue of demonstratives). Spatial deixis is lexicalized by different parts of speech in different languages: by adverbs of place (e.g., here and there), verbs (come and go) and demonstratives. The demonstratives this and that are usually considered to be spatial deictics in their basic use. For instance, this house and that house indicate closeness to and distance from the speaker. This is called a proximal deictic and that - a distal deictic. Some languages have demonstratives with 3 and 4 way distinctions on the proximal-distal dimension. According to some Lithuanian authors, the Lithuanian language is among them and has a ternary system of demonstratives (deictic pronouns): šis is a proximal deictic, anas - distal, however tas can be used to indicate both a proximal ('near the speaker') and distal ('not near the speaker') object in Lithuanian. The aim of this research is to verify whether the Lithuanian system of demonstratives is ternary as it is stated or whether it has changed. This paper deals with two problematic cases. Therefore, first, psychological distance is considered in spoken Lithuanian and, second, frequency of usage of the pronoun tas in face-to-face communication to indicate an object that is not close to the speaker instead of anas is evaluated.
\end{abstract}

Keywords: binary system; exophoric demonstratives; experiment; Lithuanian; spatial deixis; spatial opposition; ternary system.

\section{Introduction}

According to "Lietuvių kalbos gramatika” (A Grammar of Lithuanian) (Ulvydas 1965), the demonstrative pronouns šis 'this', tas 'that' and anas 'that' refer to known things in the speaker's respect. The demonstrative pronoun tas 'that' distinguishes a more or less distant known object (Ulvydas 1965, 678-679), e.g.:
(1) Tie
grūdai,
kuriuos
tèvas
uždirbo
that.NOM.PL.M grain.NOM.PL.M
that.INSTR.PL.M father.NOM.M earn.PST.3
vasara
kasdamas
griovius, pasibaige.
summer.ACC.F
dig.PTCP.M
ditch.ACC.PL.M end.PST.3

'Those grains, that the father earned by digging ditches during the summer, are used up.' 
The demonstrative pronouns šis, šitas 'this' distinguish a very close object to the speaker in perspective of space and time (Ulvydas 1965, 679), e.g.:

(2) Išgerk,

drink.IMP.2 drink.IMP.2

ipils

sesele

broleli,

šita, ipils,

pour.FUT.3

sister.NOM.F.

brother.vOC.M.

this.ACC.

pour.FUT.3

kita.

'Drink, drink, the little brother, this one, the little sister will pour, will pour another one.'

The demonstrative pronoun anas 'that' distinguishes the most distant thing (from the speaker) in perspective of space and time (Ulvydas 1965, 679), e.g.:

(3)

$\begin{array}{lllll}\text { Atameni } & \text { anaji } & \text { berniuka, } & \text { kuriam } & \text { buvo } \\ \text { remember.PRS.2 } & \text { that.ACC.M } & \text { boy.ACC.M } & \text { who.DAT.M } & \text { be.PST.3 } \\ \text { žadeję } & \text { po } & \text { dirža } & \text { réžti } & \text { už } \\ \text { promise.PTCP.3 } & \text { following } & \text { belt.ACC.M } & \text { strike.INF } & \text { for } \\ \text { kiekviena } & \text { netinkama } & \text { atsakyma? } & & \\ \text { every.ACC.M } & \text { wrong.ACC.M } & \text { answer.ACC.M } & & \end{array}$

'Do you remember that boy who has been promised to be belted for each wrong answer?'

As šitas, šis and anas indicate the most distant things from each other in perspective of space and time, they are usually opposed in different contexts (Ulvydas 1965, 679), e.g.:
(4)

$\begin{array}{lllll}\begin{array}{l}\text { Duok } \\ \text { give.IMP.2 }\end{array} & \text { me.DAT } & \text { ana, } & \text { šito } & \text { nenoriu. } \\ \text { 'Give me that one, I do not want this one.' } & \text { NEG.want.PRS.2 }\end{array}$

According to Albertas Rosinas (1988, 50-51; 1996, 57-59), the Lithuanian system of demonstratives (deictic pronouns) is ternary (see Scheme 1):

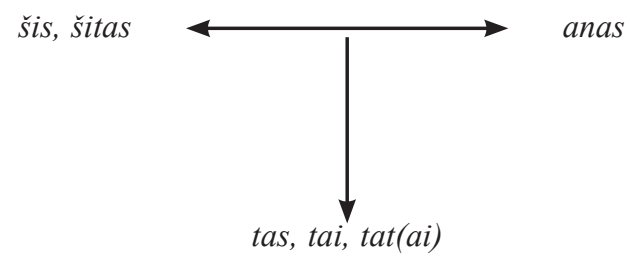

Scheme 1. The Lithuanian system of demonstratives according to Rosinas.

He states that the pronoun šis is a proximal deictic, anas - distal, however tas can be used to indicate both - a proximal ('near the speaker') and distal ('not near the speaker') object in Lithuanian (Rosinas 1996, 58-59), e.g.: 
(5)

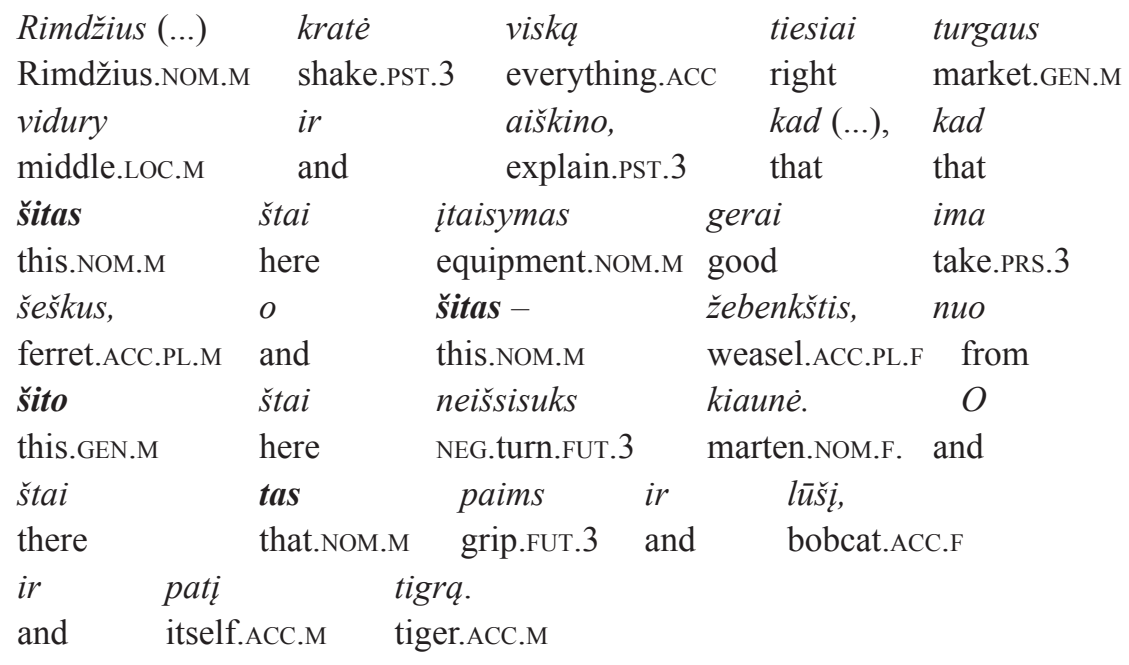

'Rimdžius (...) shook out everything right in the middle of the market and explained that (...), that this equipment is good for ferrets, and this - for weasels, and a marten won't escape from this one. Meanwhile that one will grip a bobcat and a tiger itself.'

(6) Kunigaikštis sako, rodydamas ị vaikus.

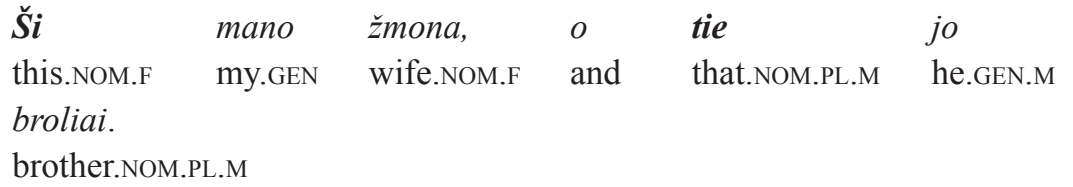

'The Duke says while pointing at the children. This is my wife, and those are his brothers.'

In the example (5) the pronoun tas is used as a synonym for the pronoun šitas, while in the example (6) the proximal-distal opposition is maintained.

After researching the semantic structure of pronouns šis, tas and anas, Rosinas concludes that all three Lithuanian pronouns can be described as follows:

šis: 'deictic', 'unemphatic', 'identical', 'demonstrative', 'direct', 'distant', 'proximate'.

tas: 'deictic', 'unemphatic', 'identical', 'demonstrative', 'direct', 'nondistant';

anas: 'deictic', 'unemphatic', 'identical', 'demonstrative', 'direct', 'distant', 'non-proximate (far)'.

Thus, the pronoun tas is a 'non-distant' demonstrative according to the listed semantic features. Literally it means that tas does not indicate neither a close nor distant referent. The electronic dictionary „Dabartinès lietuvių kalbos žodynas” (Dictionary of Modern Lithuanian) (Keinys 2011) gives precisely the same explanation: '1. Points at the object which is discussed'. Examples do not show distance either (Keinys 2011): 
(7)
Prašyk
$t \tilde{\boldsymbol{o}}$
ask.IMP. 2
$\boldsymbol{t} \tilde{\sigma}$
žmogaus.
man.GEN.M

'Ask that man.'

(8) Tasaĩ

that.NOM.M

medis

tree.NOM.M

gerai
good

'That tree grows well.'

(9) Kaip

how tóji
that.NOM.F

mergina

girl.NOM.F auga.

grow.PRS.3

'How do you find that girl?'

According to „Dabartinès lietuvių kalbos gramatika” (A Grammar of Modern Lithuanian) (Ambrazas 2006), demonstrative pronouns usually refer to a definite thing (person, phenomenon): tas, ta 'this', 'that', šis, ši šitas, šità/šita 'this (one here)', anas, ana 'that (one)' (Ambrazas 2006, 262). They exhibit/express contrast between the 'near' (šis, ši, šitas, šitàlšita) and 'distant' (anas, ana) reference (Ambrazas 2006, 263). Tas, ta are the neutral members of the near-distant opposition: they can be contrasted both to šis, ši, šitas, šita/šita and anas, ana. They are also used when no contrast between the near and distant reference is implied.

Concluding everything that has been said, several issues should be discussed. Firstly, the data reveals the ternary system of demonstratives in Lithuanian. However, the system is treated differently. According to „Lietuviu kalbos gramatika" it consists of three members: 'near the speaker' (šis, šitas), 'not near the speaker' (tas), 'not near the speaker, at the longest distance from the speaker' (anas). According to Rosinas and „Dabartinès lietuviu kalbos gramatika”, the system consists of the opposition 'near the speaker' (šis, šitas; tas) / 'not near the speaker' (anas; tas).

These differences inspired the aim of the current research, which is, by means of experiment, to determine the meaning of the pronoun tas in current spoken Lithuanian and to verify whether the Lithuanian system of demonstratives is ternary. An affirmative answer would lead to the next step, which is to review, how the spoken Lithuanian system of demonstratives has changed.

The paper consists of several parts. First, a brief overview of the theoretical background is presented. Next, the analysis and results are discussed. Finally, conclusions are drawn.

\section{Theoretical Background}

Spatial deixis. Spatial/space deixis or place deixis is one of the main kinds of deixis, when the lexical means refers to a place or places in respect of participants of actual speech act (Huang 2006, 132). Demonstratives are used to encode deictic information in a language. English demonstratives this and that are usually considered to be spatial deictics in their basic use. For instance, this house and that house indicate closeness and distance from the speaker. Other tools in languages 
are adverbs of place (like English here and there). In some languages, such as English, German or Italian, it can also be expressed by deictic verbs (like English come and go, German gehen and kommen, Italian andare and venire).

Charles Fillmore describes spatial deixis as 'that aspect of deixis which involves referring to the locations in space of the communication act participants; it is that part of spatial semantics which takes the bodies of the communication act participants as significant reference objects for spatial specification' (Fillmore 1982, 7).

Deictic words which indicate location can be classified in various ways. The most common way is to group them according to the distance from the deictic centre - the speaker. ${ }^{1}$ Following this, deictic structures are classified into proximal and distal (physical distance). The first one indicates referents near to the speaker, the second one - not near/far away from the speaker (Yule 1996, 9-10). On this basis, the world's languages are classified into single-member, binary, and trinary systems of demonstratives (as referred in the beginning of this paper, the Lithuanian language belongs to the group of languages that have a three-membered system of demonstratives).

Classification of demonstratives within a ternary system. From the point of view of the deictic centre (in this paper - the speaker) systems of demonstratives can be binary or ternary. Some languages have demonstratives with 4 and 5 way distinctions on the proximal-distal dimension (Huang 2006, 154-156). A binary system consists of proximal and distal pronouns, e.g.: English this (close to the speaker) and that (at a distance from the speaker). A ternary system has a proximal member, a medial member and a distal member. In this system the medial member locates a place, related to the deictic centre (mostly the speaker) (Huang 2006, 152-154). For example, according to John Lyons, the Turkish ternary system has these members: $b u$ 'close to the speaker', ${ }_{3} u$ 'not close to the speaker', $o$ 'at a distance from the speaker and from the listener' (Lyons 1977, 669) (see Figure 1).

\footnotetext{
In the Anglo-American tradition (Fricke 2007, 17-53) the speaker considers himself as a deictic spatiotemporal zero-point (Lyons 1977, 638) in the moment of utterance and relates everything to his viewpoint: 'The canonical situation-of- utterance is egocentric in the sense that the speaker, by virtue of being the speaker, casts himself in the role of ego and relates everything to his viewpoint. He is at the zero-point of the spatiotemporal coordinates of what we will refer as the deictic context'. The European tradition, in the line of Karl Bühler (1934), defines deixis as origo dependency and considers deictic expressions as obligatory origo-relative (Fricke 2007, 17-53). Conceptually it is understood as the origin of a coordinate system of subjective orientation (Bühler, 1934/1982a, 102), which is used to organize the personal, spatial, and temporal structure of utterances. Bühler (1990, 117) assumes one single origo for all dimensions, a mutual coordinate starting point for personal, local, and temporal deixis.
} 


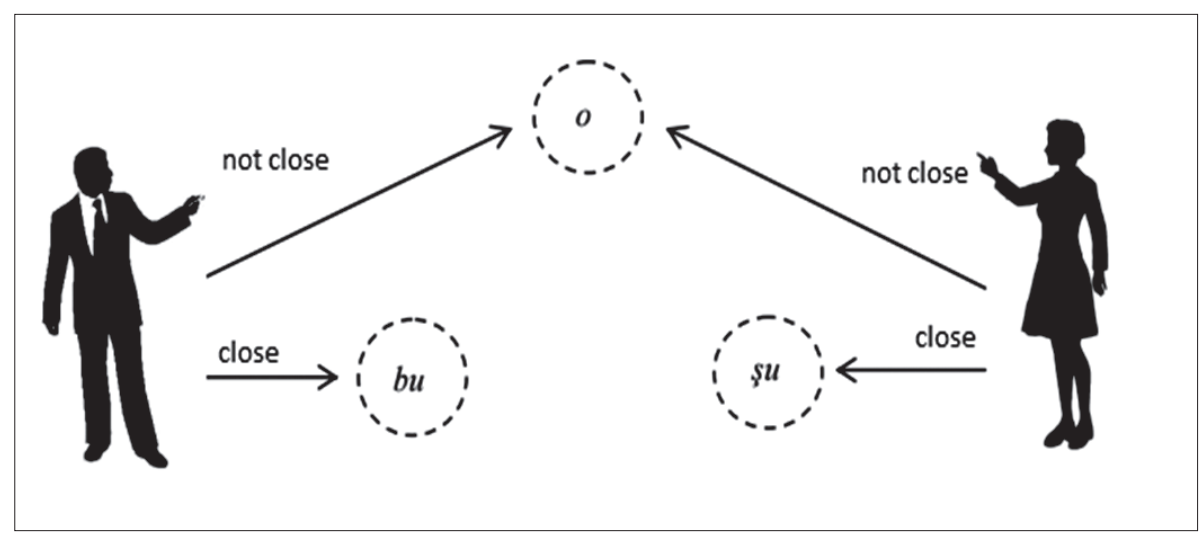

Figure 1. The Turkish ternary system of demonstratives. ${ }^{2}$

As it was already mentioned (see 1. Introduction), the Lithuanian pronoun tas is 'deictic', 'unemphatic', 'identical', 'demonstrative', 'direct', but 'non-distant'. From this point of view, the demonstrative tas has a neutral meaning in respect of distance. There are some languages across the world where demonstratives can also be distance-neutral (Churchward 1953, 150-152). In the case of distanceneutral demonstratives, the distance of the referent from the speaker is expressed by adding demonstrative adverbs to the neutral form. For instance, in German, demonstrative adverbs hier 'here' and $d a$ 'there' are added to the neutral forms dieser and stressed der, das, die (Diessel 2005):

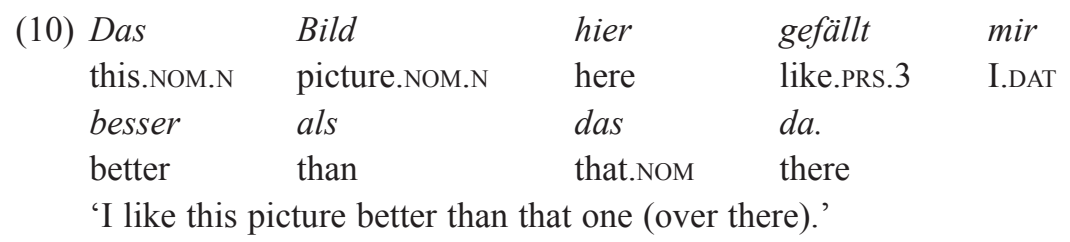

Exophoric and endophoric use. The use of demonstratives can be divided into exophoric (situational) and endophoric (textual) (Halliday and Hasan 1976). A demonstrative is used exophorically when the speaker refers directly to something that is physically evident in his surroundings. A demonstrative is used endophorically when it refers to a referent that exists in the ongoing discourse (in written text or spoken language).

Gestural deixis. The combination of language and gesture is especially characteristic of the exophoric use, in which demonstratives refer to specific entities in the surrounding situation (cf. Levinson 2004). Different methods of research classify gestures differently; however, four main types of gestures can be distinguished: iconic gestures, metaphoric gestures, deictic gestures, beats gestures

2 Drawn by Darius Stanevičius. 
(McNeill 1992, 78-81). The prototypical deictic gesture is an extended 'index' finger, but almost any extensible body part or held object can be used (e.g. hand, eyes, head, chin, etc.). Indeed, some cultures prescribe deixis with the lips (Enfield 2001). Deixis entails locating objects, subjects and actions in space vis-à-vis a reference point, which Bühler called the origo, and Lyons zero-point (McNeill 1992, 78-81). Namely, deictic gestures specify meanings of demonstratives.

Distinction based on psychological distance. According to George Yule, the truly pragmatic basis of spatial deixis may actually be psychological distance. Psychically close objects will tend to be treated by the speaker as psychologically close. Something that is psychically distant will generally be treated as psychologically distant. However, the speaker may also wish to mark something that is psychically close as psychologically distant (Yule 1996, 13). For instance, the utterance tas namas 'that house' instead of šis namas 'this house' could express the speaker's opinion upon the object of discussion.

Hypotheses. Summarising all the insights, it is possible to raise three hypotheses:

1. The Lithuanian pronoun anas as an exophoric demonstrative is the marked member of the Lithuanian system of demonstratives. In the exophoric usage it is replaced by the Lithuanian pronoun tas.

2. If the Lithuanian pronoun anas in the exophoric usage is the marked member and is replaced by the pronoun tas, the Lithuanian system of pronouns tends to be binary rather than ternary: it should follow that the pronoun šis 'this' contrasts with the pronoun tas 'that' (šis 'proximal'/tas 'distal' rather than šis 'proximal'/anas 'distal'; whereas the pronoun tas has a neutral meaning).

3. The third hypothesis of this paper is that the choice of demonstratives is not only affected by the location of the referent, but also by visual accessibility of the referent and the need for contrast. Psychological aspects are important here as well.

\section{Methods}

\subsection{Combined methods}

The data on the usage of exophoric demonstratives in ongoing interactive situations was collected via an experimental method. This approach adopted and merged the perspective of physical distance (Coventry et al. 2008) and psychological distance (Yule 1996, 13). The role play perspective (Piwek, 2008) was combined with the (free style) dialogue (Niebaum, Macha 2006, 11-50; Löffler 2003, 40-52). In addition, gestural deixis was examined. Broadly speaking, gestural deixis refers to deictic expressions whose comprehension requires some sort of audio-visual information. A simple example is an object which is pointed at and referred to as 'this' or 'that'. However, the category can include other types of information than pointing, such as direction of gaze, tone of voice, and so on. 


\subsection{A dialogue game}

According to Piwek, Beun, Cremers (2008), who researched deictic demonstratives in Dutch, one of the methods to examine the differences in use between distal and proximal demonstratives is a dialogue game. They have proposed to define such dialogue game in terms of four components/parameters (Piwek, Beun, Cremers 2008, 11). A dialogue game consists of:

1. A set of participants;

2. An initial state of play;

3. A joint public goal state, which the participants are supposed to achieve;

4. A role function, which assigns to each of the participants its entitlements, prohibitions and abilities to access.

In the present paper this method was applied as follows:

1. The set of participants consists of two subjects.

2. In the initial state all the participants (pairs) are separated and located in different places. They are facing the same referents to be located. One of the participants is located closer to the objects or subjects to describe, the other one is located further. The participants have been informed about their tasks in the pre-test briefing and have been given oral instructions ensuring the possibility to ask questions if necessary.

3. The goal state is achieved when all the subjects and objects around the pair are located and these locations are understood correctly.

4. One of the participants is assigned the role of an interviewer (the first speaker, further referred to as S1). The other participant is assigned the role of an interviewee (the second speaker, further referred to as S2). Both S1 and S2 can point at and observe all objects and subjects present on the researched location. They are allowed to talk with each other by using gestures.

\subsection{Participants and material}

In total, 11 participants (1 man, 10 women), all native Lithuanian speakers aged 20-22 took part in the experiment. All the participants were students. They were asked to talk in standard Lithuanian. One instructor explained the process and asked students to answer the questions using Lithuanian demonstratives when describing objects and persons. Students were grouped in pairs and exchanged roles. At first, one person of the pair was an interviewer, while the second one was an interviewee; then they exchanged roles. The experiment was carried out in the Cathedral Square, Vilnius, where two situations were staged: 1) the interviewer asked to localize objects seen in the Cathedral Square or around it; 2) the interviewer asked to describe all the people who were passing by or doing something in the Cathedral Square. In total 33 video films were recorded, each 1-2 minutes long (in total about 50 minutes of video material). All participants gave their consent to participate and be video-recorded. 


\subsection{The method of data analysis}

At first unsuitable material was rejected. Videos in which participants tried to artificially use all three Lithuanian demonstratives (šis, tas and anas) even though it was enough to use two (šis and tas), were considered to be inappropriate material ${ }^{3}$. The collected data was decoded, transcribed and analysed. Attention has been paid to the use of demonstratives šis, tas and anas, the current physical place of participants, gesture use and descriptions of localization. The use of demonstratives was analysed and divided into two groups: a) demonstratives which locate objects and subjects in space (physical distance); and b) demonstratives which express the speakers' opinion upon objects and subjects.

\section{The Lithuanian System of Demonstratives}

\subsection{Results: Physical Proximity and Distance}

Physical proximity. In the majority of cases, the Lithuanian pronoun šis as a 'proximal' and tas as a 'distal' to express physical distance were used. Physical proximity was expressed in both games (locating objects and identifying people), e.g.:

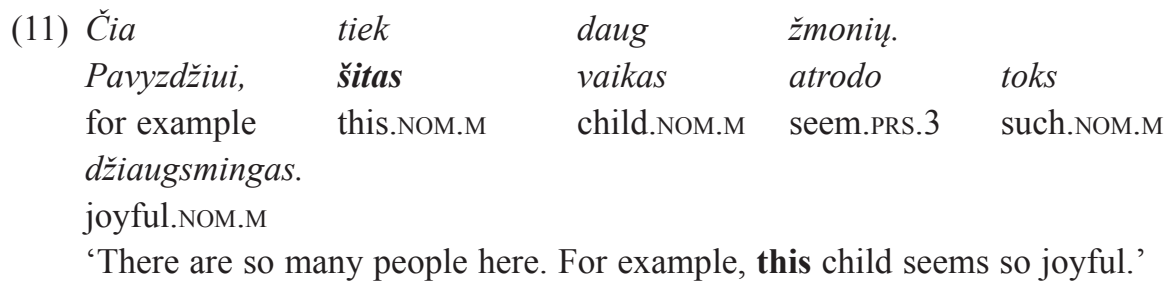

In the example (11) S1 points with a head gesture at an approaching child, who is relatively close in comparison with people standing or moving further. Therefore, physical proximity is lexicalized with the Lithuanian pronoun šis.

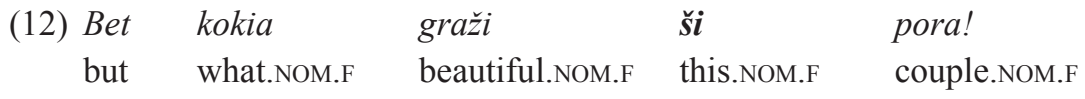

'How beautiful this couple is!'

In the example (12) S1 uses body movement and eye contact (see Figure 2) to locate the referent (which is an approaching beautiful couple) in this statement. Physical proximity is also expressed with the lexeme šis. This combination of a pronoun and a gesture helps participants to locate the subject and to share information.

3 E.g. S2 while referring to a distal subject/object chooses the demonstrative pronoun tas, but in a moment changes it to anas. Such cases were not included into the research as unclear ones. 


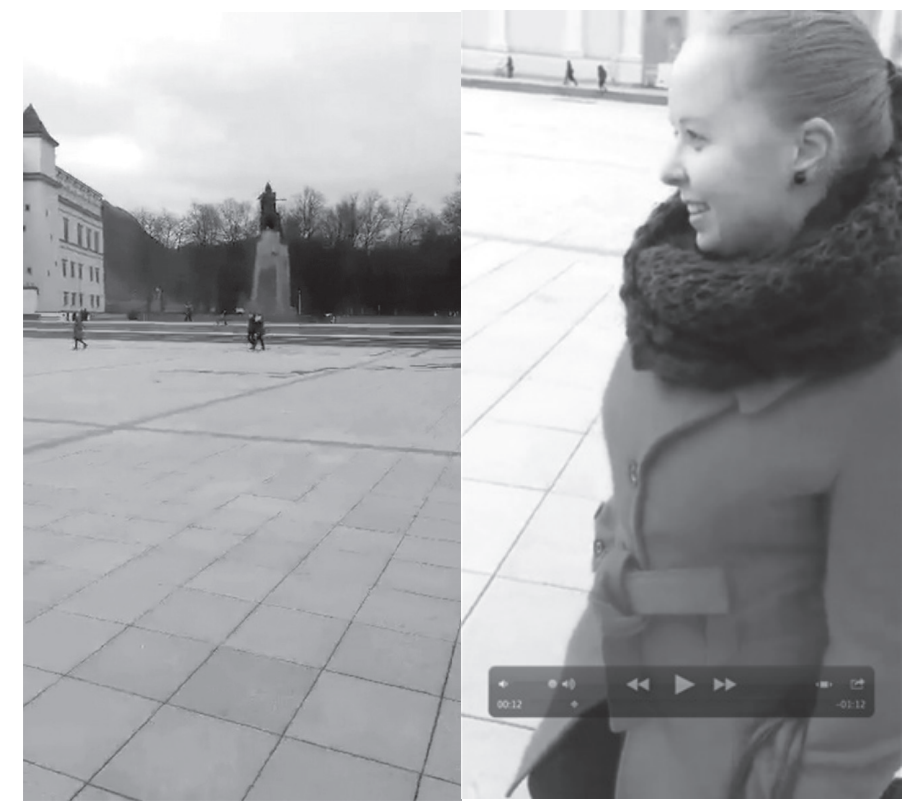

Figure 2. Physical proximity expressed by the pronoun šis and a body gesture.

Physical distance. In almost all cases (except one, which will be explained further) physical distance was lexicalized with the Lithuanian pronoun tas and specified by different gestures.

\begin{tabular}{|c|c|c|c|c|c|}
\hline (13) S1: & $\begin{array}{l}O \\
\text { and }\end{array}$ & $\begin{array}{l}\text { kaip } \\
\text { how }\end{array}$ & $\begin{array}{l}\text { tau } \\
\text { you.DAT }\end{array}$ & $\begin{array}{l}\text { tas } \\
\text { that.NOM.M }\end{array}$ & $\begin{array}{l}\text { bokštas? } \\
\text { tower.NOM.M }\end{array}$ \\
\hline S2: & $\begin{array}{l}\text { 'And how } \\
\text { Tas } \\
\text { that.NOM.M } \\
\text { demesi. } \\
\text { attention.Ad }\end{array}$ & $\begin{array}{l}\text { you find tha } \\
\text { bokštas } \\
\text { tower.NOM.M }\end{array}$ & $\begin{array}{l}\text { ower?' } \\
\text { tikrai } \\
\text { certainly }\end{array}$ & $\begin{array}{l}\text { atkreipia } \\
\text { attract.PRS.3 }\end{array}$ & \\
\hline
\end{tabular}

'That tower certainly attracts attention.'

In the given example participants are talking about the tower of the Cathedral Square, which is quite at a distance from them. They are both using the pronoun tas which is followed by a hand gesture pointing to the tower to locate the object.

In the next examples (14), (15) the same hand gestures are used. In the example (14) a hand gesture is used in combination with the distal Lithuanian pronoun tas: $\mathrm{S} 1$ uses a hand gesture pointing at a bookstore (a different referent); S2 does not use any gesture as the location of the bookstore is clear after the question is asked. In the example (15) (see Figure 3) the pronoun tas in a combination with a hand gesture was used in the answer; the hand gesture points at the Amberton hotel and helps S1 comprehend the situation: 
(14) S1: $O$

$\begin{array}{lllll}O & \text { tas? } & O & \text { tas } & \text { knygynas? } \\ \text { and } & \text { that.NOM.M } & \text { and } & \text { that.NOM.M } & \text { bookstore.NOM.M }\end{array}$
'And that? That bookstore?'

S2: Manau, kad to knygyno vaizda think.PRs. 1 that that.GEN.M bookstore.GEN.M view.ACC.M labai gadina plakatas. very spoil.PRS.3 poster.NOM.M

'I think that the view of that bookstore is spoilt by a poster'

(15) S1: Kokiame pastate labiausiai norètum apsilankyti?

'Which building would you like to visit?'

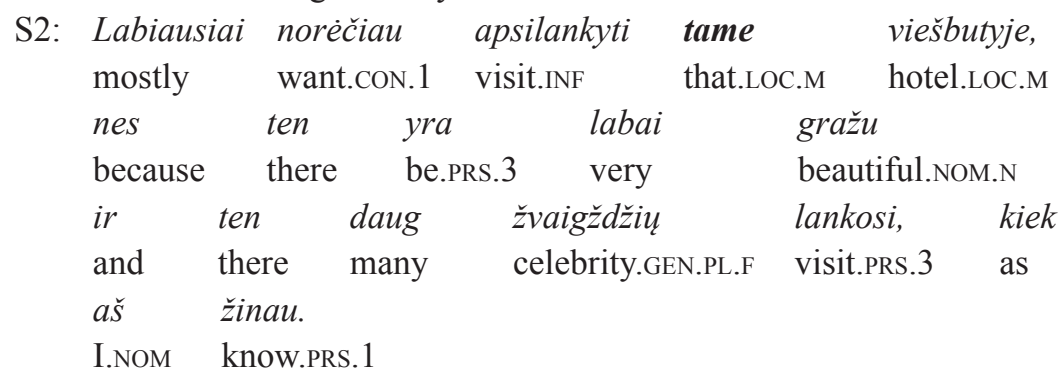

'I would like to visit that hotel, because it is very beautiful inside and, as far as I know, lots of celebrities visit it.'

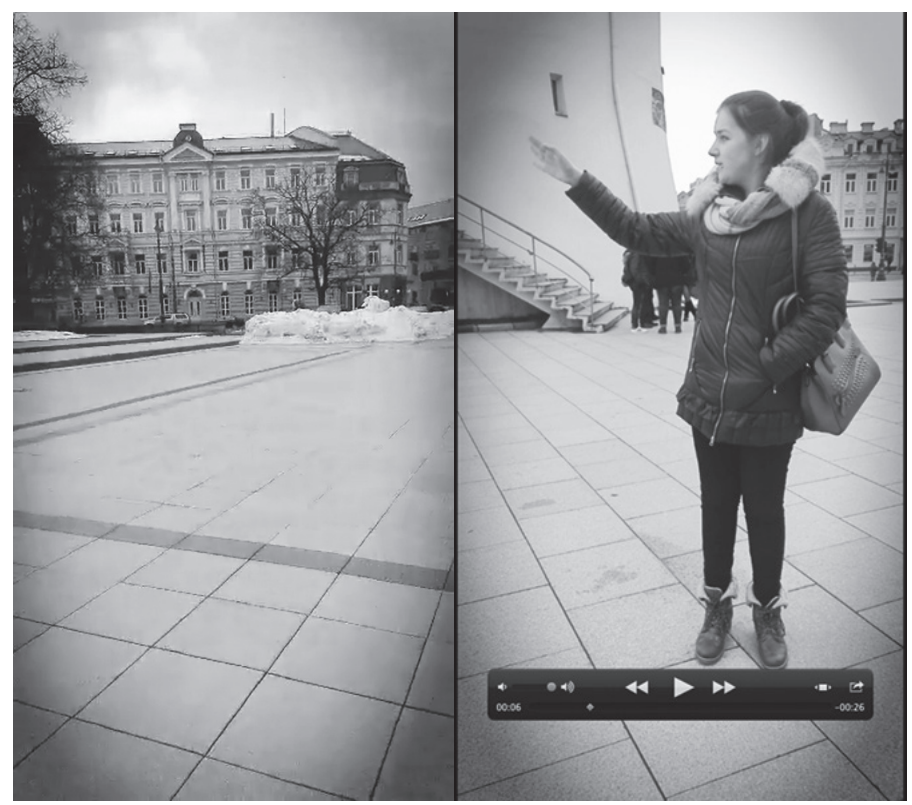

Figure 3. Physical distance expressed by the pronoun tas and a hand gesture. 
Sometimes the distal Lithuanian pronoun tas is specified by a head movement pointing at the referent, e.g. in the example (16), where S1 asks his question and turns his head to show S2 the subject of discussion:

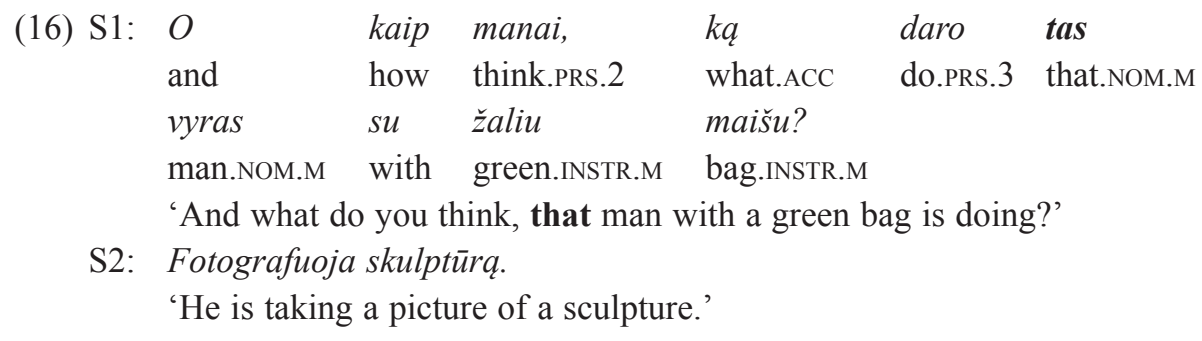

A binary opposition of physical proximity and distance is evident when S1 and S2 are locating different subjects in the same conversation. In the current case different Lithuanian pronouns (šis 'proximal' and tas 'distal') are chosen. After examining the next dialogue (example (17)), it is quite clear, that the choice of demonstratives is affected not only by the location of the referents (the bell tower and the building), by visual accessibility of the referents, but most importantly, by the need for contrast to perceive location of referents correctly, e.g.:

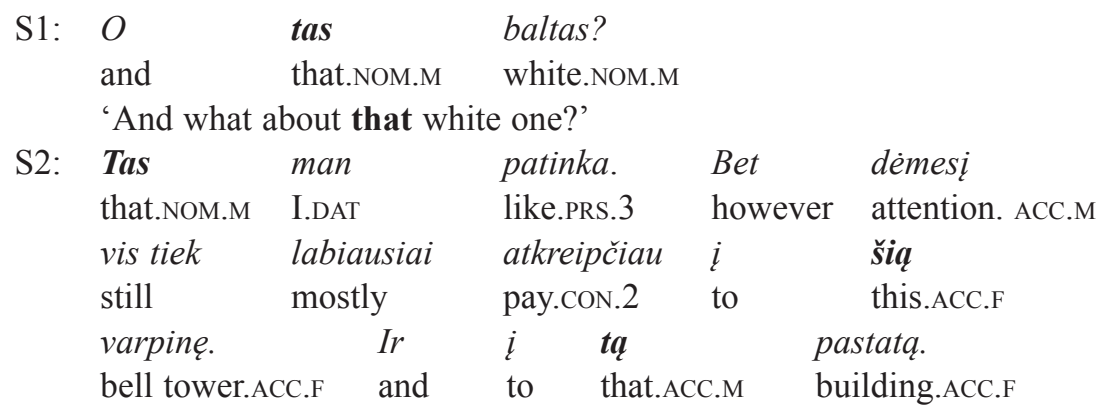

'I like that one. However, I would pay attention mostly to this bell tower. And to that building.'

As bell tower was located closer to S2 and the other building was at a distance from S2, he selects this opposition of the corresponding Lithuanian pronouns and shows contrast to $\mathrm{S} 1$.

Changing physical distance. The results of the current research also confirmed that the choice of demonstratives is affected by visual accessibility of the referents. The analysis showed that in some cases during the ongoing conversation the same referent is pointed at by a different pronoun. For example, when referring to an object or subject, S1 chooses the proximal pronoun šis, while S2 chooses the distal pronoun tas. Several reasons can determine the choice: 1) the choice depends on the location of the speakers (example (18)): S1 is standing closer to the referent; S2 is standing further from the referent; 2 ) the referent is moving at the moment of the actual dialogue (examples (19), (20)).

In the example (18) S1 and S2 are identifying the same referent which is a woman they both see. S1 stands closer to the referent and selects the proximal 
Lithuanian pronoun šita (see Figure 4: S2 stands behind the camera, further from the referent; S1 stands in front of S2, closer to the referent). As S1 does not use any gesture, she describes the referent and uses a description su ilga kasa 'with a long braid'. S2 wants to be sure about the referent, thus she tries to specify the information (uses a description su raudonu šaliku? 'wearing a red scarf?'), but instead of the proximal pronoun šita, she uses the distal pronoun $t a$. The choice was influenced by the location of $\mathrm{S} 2$ - she stands at a distance from the referent in comparison with $\mathrm{S} 1$.

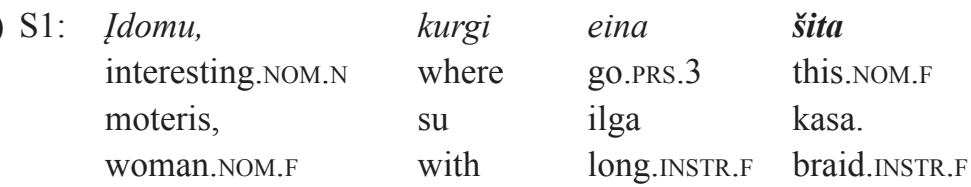

'I wonder where this woman is going, the one with a long braid.'

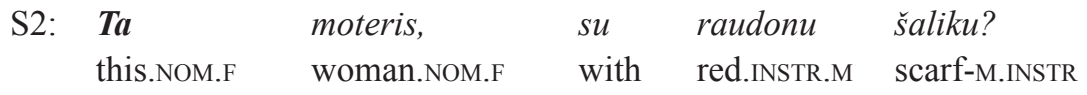

'That woman, wearing a red scarf?'

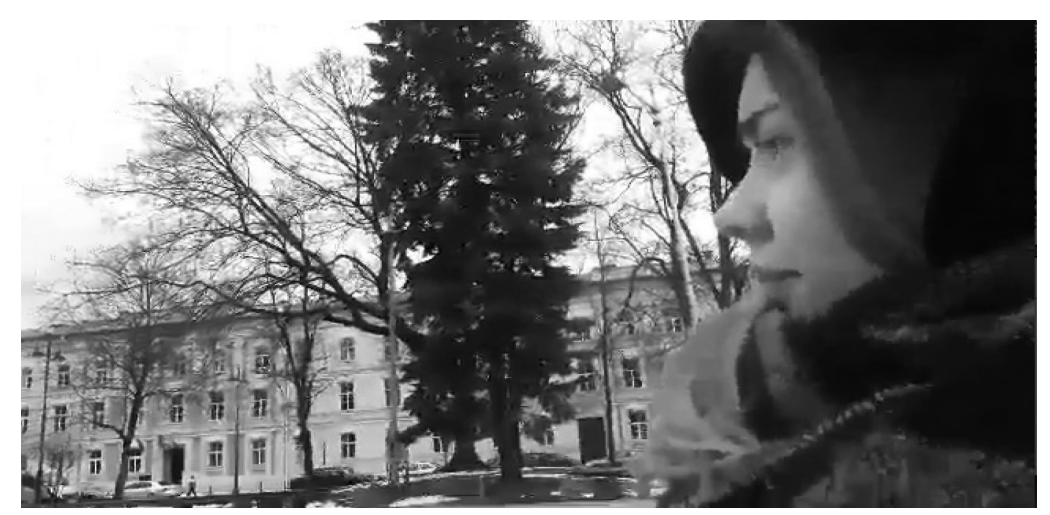

Figure 4. The referent (people) is closer to the participants. ${ }^{4}$

In the examples (19) and (20) the referents are moving, hence attention is paid to the movement, not to the position of the participants. In the example (19) the participants identify the same referent, which is a group of people they both see (see Figures 5 and 6). The situation is complicated due to the group changing its location (moving), and the participants want to be clear about the referent. S1 asks a question and tries to identify the location of the group by using the proximal pronoun šiuos. S2 answers the question and specifies her answer by moving her body to point at the referent. However, S2 chooses to use the distal Lithuanian

$4 \quad$ No pictures, where both speakers are seen, were made. These pictures are snap shots made when the video was paused. S1 and S2 change their roles which results in just one of them being seen on the screen: in case S1 is seen, S2 stands behind the camera and vice versa. This performance was taken into consideration while analysing different contexts, e.g. if S1 stands in front of S2, it means S1 stands closer to the referent, and S2 is further from the referent. The position was taken into consideration when it was needed. 
pronouns $t a, t i e d u$ and tas, because the referent (the group) has changed its position during the actual conversation and moved forward. This example is opposite to the example (18), while according to the positions of the speakers different pronouns should be used in the example (19): S1 should have used the distal pronoun and S2 should have selected the proximal Lithuanian pronoun. The choice was influenced by the evident change of the referent's location.

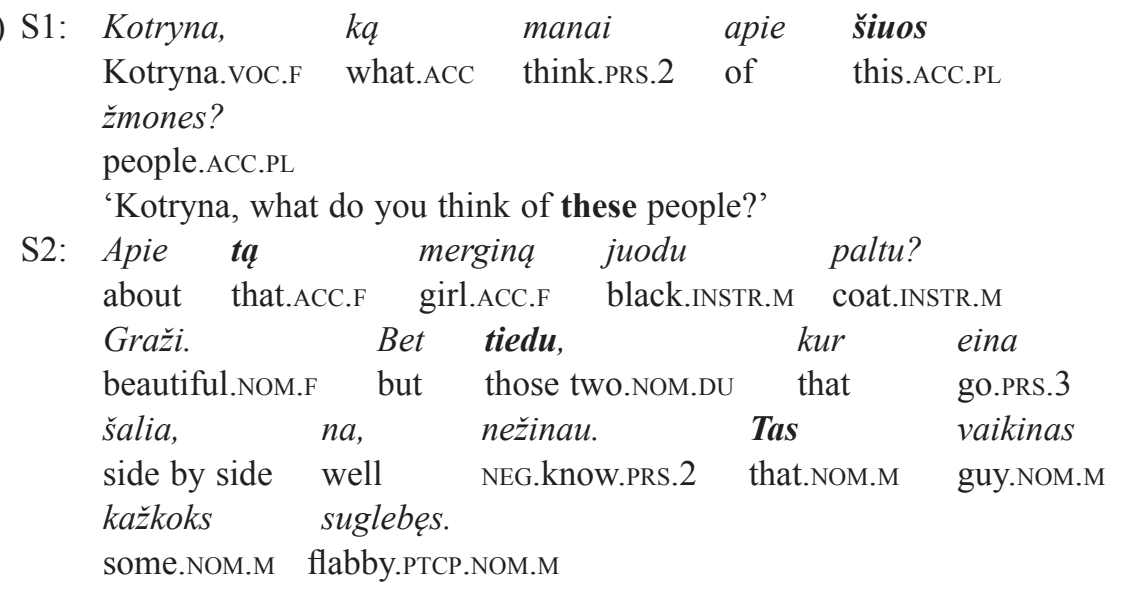

'About that girl in a black coat? Beautiful. But the two that are walking side by side, well, I do not know. That guy seems flabby.'

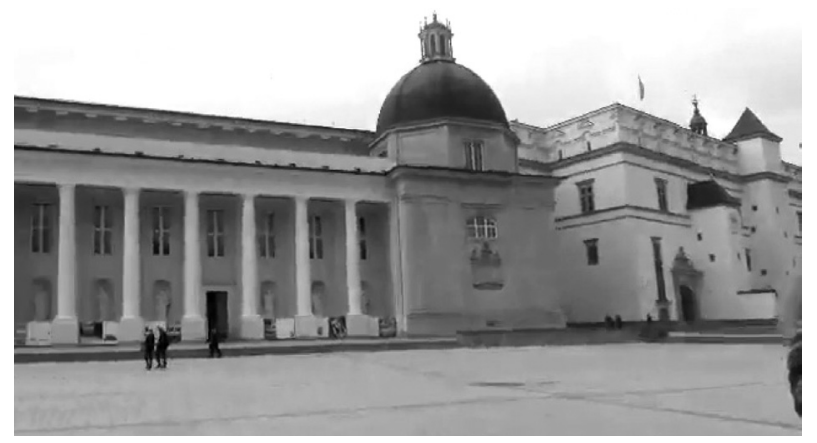

Figure 5. The referent (people) is closer to the participants.

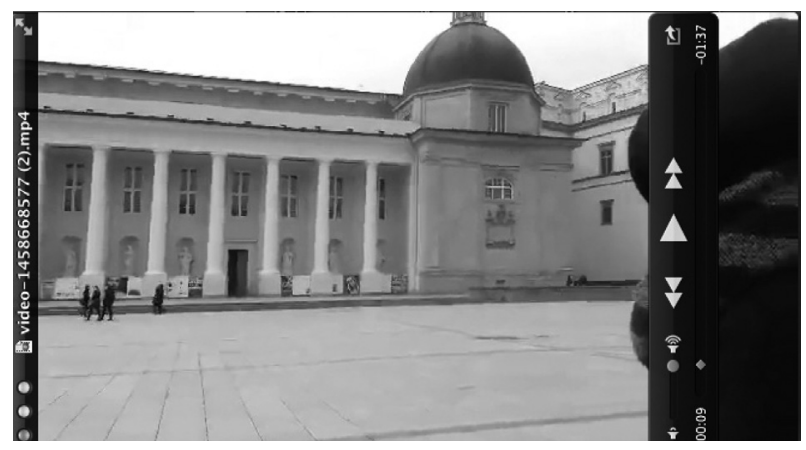

Figure 6. The referent (people) is further comparing to the previous figure. 
A very similar dialogue was recorded, where a location of a different referent was identified. In the example (20) localization is also complicated due to the referent (a man) changing his location (moving): when S1 utters a sentence, the referent is approaching S1 and S2, and when S2 starts her sentence, he is moving away from the participants.

$\begin{array}{lllll}\text { Šitas } & \text { vyras } & i & \text { mus } & \text { žiūrejjo, } \\ \text { this.NOM.M } & \text { man.NOM.M } & \text { to } & \text { we.ACC } & \text { look.PST.3 } \\ \text { nes } & \text { mes } & \text { atrodome } & \text { labai } & \text { keistai. } \\ \text { because } & \text { we.NOM } & \text { look.PRS.PL.1 } & \text { very } & \text { weird }\end{array}$

'This man looked at us, because we look very weird.'

S2: Aš tikiu, kad mes atrodome keistai.

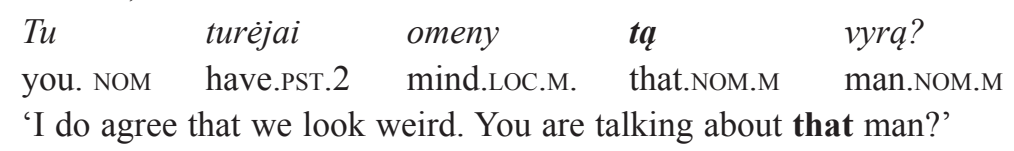

The pronoun anas. According to Rosinas, the Lithuanian pronoun anas belongs to the system of direct pointing pronouns (demonstratives). It belongs to a space (spatial) deixis and enters the ternary system of demonstratives in standard Lithuanian. Anas is a 'distal' pronoun and performs as a deictic. In addition, anas is a member of the opposition 'proximal' (šis, šitas) / 'distal' (anas) (Rosinas 1996, 58-59).

In this experiment only one dialogue with the Lithuanian pronoun anas was recorded (see example (21)).

(21) S1: O už katedros, yra kalnas.

'And behind the cathedral, there is a hill.'

S2: Kuris kalnas?

'Which hill?'

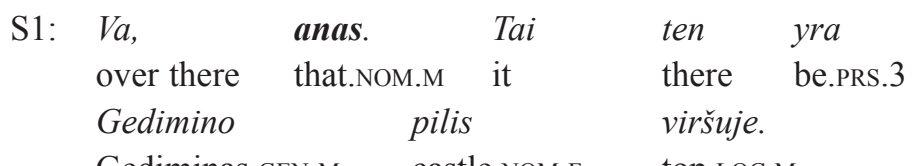

Gediminas.gEN.M castle.NOM.F top.LOC.M

'Over there, that one. There is Gediminas Castle on the top of it.'

The only case when a participant, S1, has chosen the so-called distal pronoun anas, was due S2 question. This dialogue shows that S2 has not identified the object as there were two hills in front of them. To be specific, S2 asks to repeat which hill is the object of discussions. Only then S1 uses the distal pronoun anas together with a hand gesture to point. The purpose of this usage is to draw attention, to define, to explain correctly.

Summary. To sum up, it is necessary to pay attention to the so-called distal Lithuanian pronoun anas. It is quite clear that in spoken Lithuanian the proximal/ distal opposition is maintained by different pronouns. To lexicalize proximity native Lithuanian speakers choose the pronoun šis, šita. However, the first choice 
to express distance in Lithuanian is the pronoun tas, ta, not anas as it was stated in previous studies. Second, as the choice of demonstratives also depends on the need for contrast: in some cases participants interpret themselves as one reference point in face-to-face communication.

\subsection{Results: Psychological Proximity and Distance}

Yule suggests classifying deictic structures on the basis of psychological distance. According to this classification, deictic words are classified into psychologically close and psychologically distant. He explains this classification as follows: a place from the speaker's perspective may be determined both physically and psychologically. Physically close objects are usually perceived as psychologically close; something that is physically distant is generally considered as psychologically distant, for example, tas žmogus ten 'that man over there'. However, there may be a reverse option, when the speaker is physically close to the object, but he expresses it as if it was psychologically distant, e.g. the speaker utters man nepatinka tos kriaušès 'I do not like those pears' while eating these pears (Yule 1996, 12-13).

Psychological proximity. The results of this study show that the participants of the experiment usually felt psychologically close to the location where action took place (the Cathedral Square). This might be the main reason why examples of psychological distance were absent in the researched material. In the example (22) S1 and S2 try to identify the buildings they see around, both of them describing the buildings at a distance by using the Lithuanian proximal pronoun ši, šie (plural) and a hand gesture (see Figure 7):

\begin{tabular}{lllcc}
$\mathrm{S} 1:$ & Vilte, & kas & \multicolumn{1}{c}{ visi } & \multicolumn{2}{c}{ šie } & pastatai \\
viltè.VOC F & what & all.NOM.PL.M & this.NOM.PL.M & building.NOM.PL.M \\
aplink & mus, & ir & $k q$ & manai \\
around & we.ACC & and & what & think.PRS.2 \\
apie & šiq & aukšta & varpinę? & \\
about & this.ACC.F & high.ACC.F & bell tower.ACC.F
\end{tabular}

'Vilte, what are all these buildings around us, and what do you think about this high bell tower?'

S2: $\check{S} \boldsymbol{i} \quad$ varpine

this.NOM.F bell tower.NOM.F already be.PRs.3 bit

apgriuvusi, tačiau ši varpine

collapse.PTCP.NOM.F but this.NOM.F bell tower.NOM.F

yra Vilniaus simbolis. Pats gražiausias.

be.PRS.3 Vilnius.GEN.M symbol.NOM.M

'This bell tower is already a bit aged, but this bell tower is a symbol of Vilnius. The most beautiful one.' 


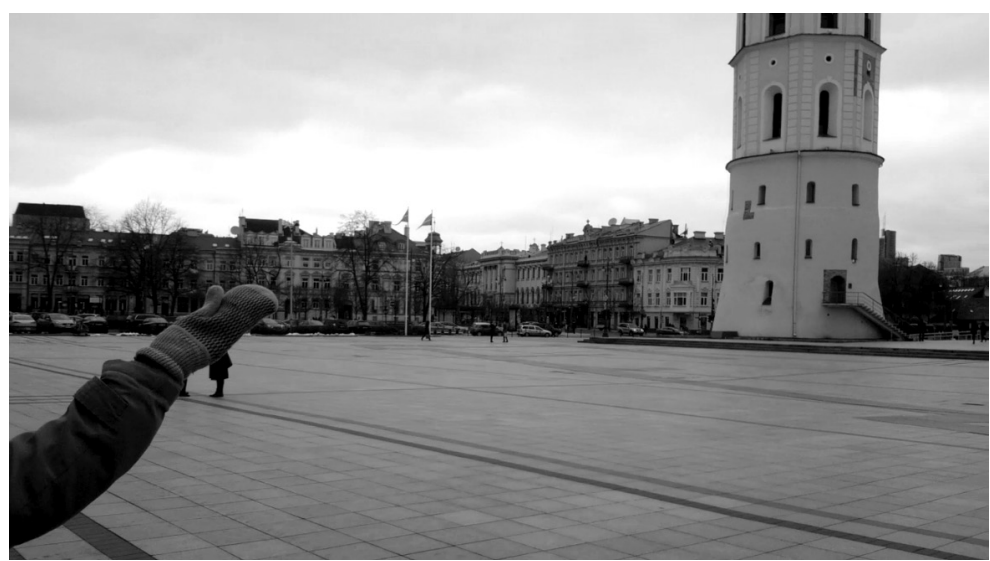

Figure 7. The referent at a distance is identified by the pronoun $̌ s i$.

In the example (23) S1 and S2 are talking about the public toilet in a distant hotel and S2 also uses the proximal Lithuanian pronoun šitam. As in the example (15), a hand gesture clarifies the meaning.

(23) S1: Kur aš galèčiau rasti viešaji tualeta??

'Where could I find a public toilet?'
S2: Iš tikruju pasakysiu paslaptí- va šitam
in fact tell.PRs.2 secret.ACC.F here this.LOC.M
viešbutyje.
hotel.LOC.M
'I will reveal you a secret - over here in this hotel.'

In the example (24) S1 and S2 are describing a bell tower, which is also at a distance comparing to their location. A hand gesture in combination with the proximal pronoun šitas points at the referent (see Figure 8). One of the reasons of this usage is psychological proximity, the other is a need for contrast. As the speakers perceive the location of the bell tower in comparison with other buildings behind, they might be drawing this contrast in their minds and using proximal pronouns.

\begin{tabular}{|c|c|c|c|c|c|}
\hline S1: & $\begin{array}{l}\text { Kas } \\
\text { what.NOM }\end{array}$ & $\begin{array}{l}\text { yra } \\
\text { be.PRS.3 }\end{array}$ & OM.M & $\begin{array}{l}\text { pastatas } \\
\text { building }\end{array}$ & \\
\hline & 'What is tl & s building?' & & & \\
\hline S2: & $\begin{array}{l}\text { Šitas } \\
\text { this.NOM.M }\end{array}$ & $\begin{array}{l}\text { pastatas, } \\
\text { building.NOM.M }\end{array}$ & $\begin{array}{l}\text { kiek } \\
\text { as }\end{array}$ & $\begin{array}{l}a \check{s} \\
\text { L.NOM }\end{array}$ & $\begin{array}{l}\text { žinau, } \\
\text { know.PRS.2 }\end{array}$ \\
\hline & yra & varpine. & & & \\
\hline & be.PRS. 3 & bell tower.NOM.F & & & \\
\hline
\end{tabular}

'This building, as far as I know, is a bell tower.' 


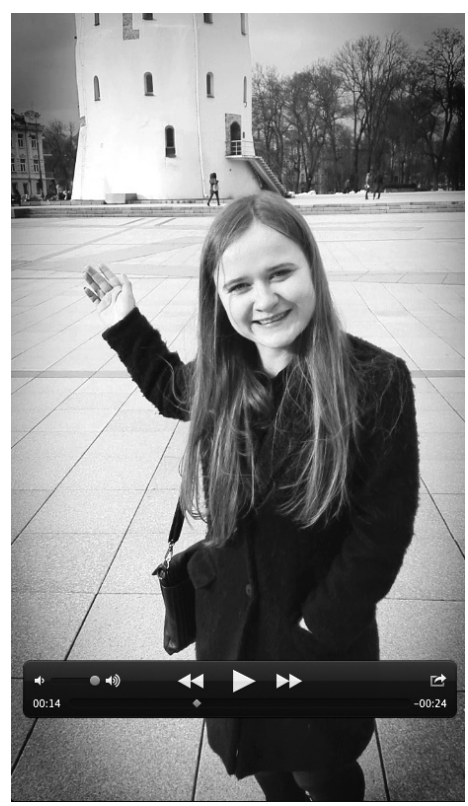

Figure 8. S2 points at a distant referent and uses the proximal pronoun šitas.

Summary. It is evident that psychological proximity is dominating in dialogues in comparison with psychological distance. There might be several reasons for that: 1) the participants felt psychologically close to the location where action took place, even to the city where the Cathedral Square is located (Vilnius); 2) they did not feel any negative emotions about the people and buildings they were discussing. When the demonstrative pronoun tas, ta gets the meaning of proximity from a psychological perspective, it becomes equal to the proximal pronoun $\check{s} i s, \check{s} i$ (see Table 1).

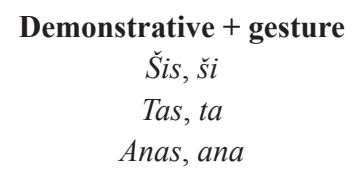

\author{
Meaning \\ 'proximal, distal' \\ 'distal' \\ 'distal'
}

Table 1. The meanings of demonstrative Lithuanian pronouns.

\section{Conclusion}

The present research aimed to verify by means of experiment whether the Lithuanian system of demonstratives is ternary as it is stated or whether it has changed. This study dealt with two problematic issues. First, frequency of usage of the pronoun tas in face-to-face communication to indicate an object that is not close to the speaker instead of anas was evaluated, and second, psychological distance was considered in spoken Lithuanian. 
The research of demonstratives šis, tas and anas has shown that the choice of pronouns is more complex than was expected. The experiment has shown that spatial opposition does have an effect on the choice of Lithuanian demonstrative pronouns and the native Lithuanian participants try to maintain this opposition even when the distance is changing. However, distance might not be the only aspect that influences the choice of demonstratives. Psychological aspects play a very important role here as well. The occurrence of the pronoun anas 'other' just once during experiment suggests that there is no need to use it, while the pronoun tas in spoken Lithuanian functions as the main distal pronoun. That leads us to the raised hypotheses of this paper.

1. This study confirmed that the pronoun anas is very rare in face-to-face communication; as an exophoric demonstrative it is the marked member of the Lithuanian system of demonstratives. The pronoun anas loses its position to refer to distal objects/subjects (the meaning "non-proximate (far)') and starts to get a new meaning in spoken Lithuanian which is 'specifying'.

2. This study confirms the second hypothesis that the Lithuanian system of pronouns tends to be binary rather than ternary (see Scheme 2). The proximal pronoun šis is opposite to the distal pronoun tas, not the distal pronoun anas.

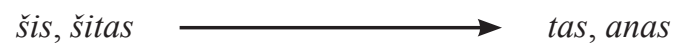

Scheme 2. The current system of Lithuanian demonstrative pronouns.

3. The third hypothesis was confirmed: the choice of demonstratives is affected not only by the location of the referent, visual accessibility of the referent or the need for contrast. The psychological aspect is also very important:

3.1 From a psychical perspective the distal Lithuanian pronoun tas is neutralized by the distal pronoun anas. Both of them have the meaning of 'distal'.

3.2 From a psychological perspective the proximal pronoun šis can be neutralized by the distal pronoun tas. Both of them gain the meaning of 'proximal'.

$\begin{array}{ll}\text { Abbreviations } \\ \text { ACC } & \text { accusative } \\ \text { COND } & \text { conditional mood } \\ \text { DAT } & \text { dative } \\ \text { DU } & \text { dual } \\ \text { F } & \text { feminine } \\ \text { FUT } & \text { future } \\ \text { GEN } & \text { genitive }\end{array}$




$\begin{array}{ll}\text { IMP } & \text { imperative } \\ \text { INF } & \text { infinitive } \\ \text { INSTR } & \text { instrumental } \\ \text { LOC } & \text { locative } \\ \text { M } & \text { masculine } \\ \text { N } & \text { neutrum } \\ \text { NEG } & \text { negation } \\ \text { NOM } & \text { nominative } \\ \text { PL } & \text { plural } \\ \text { PRS } & \text { present } \\ \text { PTCP } & \text { participle } \\ \text { PST } & \text { past } \\ \text { VOC } & \text { vocative }\end{array}$

\section{References}

1. Ambrazas, Vytautas (ed.). 2006. Dabartiness lietuviu kalbos gramatika. The fourth revised edition. Vilnius: Mokslo ir enciklopedijų leidybos institutas.

2. Bühler, Karl. (1934/1982). Sprachtheorie: Die Darstellungsfunktion der Sprache. Stuttgart \& New York: Fischer.

3. Bühler, Karl. 1990. Theory of language. The representational function of language. Translated by Goodwin, Donald Fraser. Amsterdam \& Philadelphia: John Benjamins.

4. Churchward, Maxwell C. 1953. Tongan Grammar. London: Oxford University Press.

5. Coventry, Kenny R. et al. 2008. Language within your reach: near-far perceptual space and spatial demonstratives. Cognition. 108 (3), 889-895.

6. Diessel, Holger. 2005. Distance contrasts in demonstratives. World atlas of language structures. Haspelmath, Martin, Dryer, Matthew, Gil, David and Bernard Comrie (eds). Oxford: Oxford University Press, 170-173. Available: http://www.personal. uni-jena.de/ $\sim$ Xdiho/Distance\%20contrasts.pdf [Date of access 18.09.2016.].

7. Enfield, Nick J. 2001. 'Lip-pointing': A discussion of form and function with reference to data from Laos. Gesture. 1, 185-21.

8. Fillmore, Charles J. 1982. Towards a descriptive framework for spatial deixis. Speech, place and action: Studies in deixis and related topics. Jarvell, Robert J., Klein, Wolfgang (eds). London: Wiley, 31-59.

9. Fricke, Ellen. 2007. Origo, Geste und Raum. Lokaldeixis im Deutschen. Berlin, New York: De Gruyter.

10. Halliday, M. A. K, Ruqaiya, Hasan. 1976. Cohesion in English. London: Longman.

11. Huang, Yan. 2006, Pragmatics. Oxford: Oxford University Press.

12. Keinys, Stasys (eds.). 2011. Dabartines lietuviu kalbos žodynas. The sixth (the third electronic) edition. Vilnius: Lietuvių kalbos institutas, 2006. Available: http:// dz.lki.lt/.

13. Levinson, Stephen C. 2004. Deixis. Handbook of pragmatics. Horn, Laurence R., Ward, Gregory (eds). Oxford: Blackwell, 97-121.

14. Löffler, Heinrich. 2003. Dialektologie: Eine Einführung. Tübingen: Narr. 
15. Lyons, John. 1977. Semantics. Cambridge: Cambridge University Press.

16. McNeill, David. 1992. Hand and Mind: What Gestures Reveal About Thought. Chicago: University of Chicago Press.

17. Niebaum, Hermann, Macha, Jürgen. 2006. Einführung in die Dialektologie des Deutschen. Tübingen: Niemeyer (= Germanistische Arbeitshefte 37).

18. Piwek, Paul et al. 2008. 'Proximal' and 'distal' in language and cognition: evidence from deictic demonstratives in Dutch. Pragmatics. 40(4), 694-718.

19. Rosinas, Albertas. 1988. Baltu kalbų ìvardžiai. Vilnius: Mokslas.

20. Rosinas, Albertas. 1996. Lietuvių bendrinès kalbos ịvardžiai. Vilnius: Mokslo ir enciklopedijų leidykla.

21. Ulvydas, Kazimieras (ed.). 1965. Lietuviu kalbos gramatika. 1. Vilnius: Mintis.

22. Yule, George. 1996. Pragmatics. New York: Oxford University Press.

\section{Kopsavilkums}

Raksts veltīts vietas deiksam lietuviešu valodā (norādāmo vietniekvārdu gadījumam). Vietas deikss dažādās valodās tiek leksikalizēts ar dažādām vārdšķkirām: vietas apstākḷa vārdiem (angl. here 'šeit' un there 'tur'), darbības vārdiem (angl. go 'iet' un come 'nākt'), kā arī norādāmajiem vietniekvārdiem (angl. this 'šis' un that 'tas'). Norādāmos vietniekvārdus šis 'šis' un tas 'tas' parasti uzskata par deiktiskiem. Piem., šis namas 'šis nams' un tas namas 'tas nams' norāda tuvumu un tālumu no runātāja. Šis sauc par proksimālo deiksu, bet tas - par distālo. Dažādās valodās ir 3 vai 4 norādāmo vietniekvārdu atšksirību veidi (pēc proksimālāsdistālās dimensijas). Vairāki Lietuvas autori norāda, ka lietuviešu valoda ir starp tām, kurās ir trīsdalị̄gas norādāmo vietniekvārdu sistēmas: šis ir proksimāls deikss, anas - distāls, bet tas tiek izmantots, lai norādītu gan proksimālo (pie runātāja), gan distālo (tālu no runātāja) objektu. Šì pētījuma mērksis ir, pamatojoties uz eksperimentāliem datiem, pārbaudīt, vai lietuviešu valodas norādāmo vietniekvārdu sistēma ir trīsdaḷīga, vai tā tiek mainīta. Šajā rakstā pievērsta uzmanība diviem problemātiskiem gadījumiem. Pirmkārt, pārbaudīta vietniekvārdu tas un anas izmantošana tiešā saziņā un, otrkārt, novērtēts psihologískais attālums. Pētījums apstiprina, ka vietniekvārds anas tiešā komunikācijā ir sastopams l̦oti reti, tas sāk iegūt jaunu nozīmi lietuviešu valodā. Lietuviešu valodas norādāmo vietniekvārdu sistēma ir bināra, nevis trīsdaḹiga: proksimālais vietniekvārds šis tiek pretstatīts distālajam vietniekvārdam tas, nevis anas. Norādāmo vietniekvārdu izvēli ietekmē arī psihologisiskais aspekts ne tikai referenta atrašanās vieta, referenta vizuālā pieejamība un kontrasta nepieciešamība. 